\title{
Editorial
}

\section{Sem uma enfermagem participativa, não haverá saúde de qualidade para cuidar bem das pessoas}

O tema da 76a Semana Brasileira de Enfermagem, da Associação Brasileira de Enfermagem-ABEn Enfermagem em defesa do SUS: Construindo a XVa Conferência Nacional de Saúde, se apresenta como um desafio premente para a garantia da continuidade de um projeto público e democrático de saúde para o país. Trata-se de uma convocação para que a enfermagem, como a mais numerosa categoria que compõe a força de trabalho em saúde, discuta a atual Política Nacional de Saúde para além dos seus conteúdos técnico-científicos, trazendo a centralidade da sua dimensão ético-política para o debate.

Em uma conjuntura econômica e política cercada de incertezas, os acontecimentos recentes em termos de mobilizações populares nas ruas tem se apresentado como um fenômeno marcado por opacidade de intenções, fragmentação e disparidade de projetos. Diferentemente do horizonte de lutas sociais que marcaram as décadas de 70 e 80, que buscavam a instauração de uma ordem social democrática no país, os dias atuais se caracterizam por lutas individualizadas, acompanhada por uma avalanche de informações, em sua maioria de baixa credibilidade, alimentadas pelas mídias e pelas redes sociais, que acabam por contribuir para aumentar a desinformação, em lugar de ampliar o conhecimento dos cidadãos quanto aos verdadeiros processos históricos de determinação em curso.

Nesse contexto, a reconfiguração dos interesses político e político-partidários, pretensamente unificados em torno do tema "luta contra a corrupção", parecem obscurecer outras formas de ataque às políticas públicas sociais. A argumentação em torno de um discurso de base liberal, que atribui a cada cidadão, individualmente, a culpa ou o mérito pelo seu sucesso profissional e econômico ganha força em conjunturas de esgarçamento do tecido social, como a que vivemos. As imensas dívidas sociais, ainda não sanadas, passam a ser levianamente consideradas problemas capazes de serem superados no nível individual de ação.

Os princípios que nortearam a construção do Sistema Único de Saúde brasileiro são, após mais de duas décadas de implementação, mais atuais e progressistas do que nunca. Na contramão das propostas que visam relativizar o princípio do acesso universal à saúde, o elemento que pode fazer diferença na balança política é a capacidade de mobilização dos trabalhadores em geral, e de saúde, em particular, em torno da defesa dos processos de fazer avançar o SUS naquilo que possui de mais essencial: a defesa do direito à saúde, para todos.

A enfermagem brasileira é, assim, convocada pela ABen para compor as instâncias de debate e luta, em cada município e Unidade Federativa, reconhecendo as fragilidades a serem superadas, que incluem o baixo gasto com a saúde, os desafios à formação de qualidade, adequadas e dignas condições de trabalho, dentre outros, e reafirmando o direito à saúde pública e de qualidade. Vale ressaltar que, em que pese a existência de numerosas escolas, faculdades e centros de formação, o adequado dimensionamento da força de trabalho de enfermagem não é um fato, e precisa ser considerado nessa conjuntura.

A participação da enfermagem nos processos preparatórios da XVa Conferência Nacional de Saúde - assembleias, Conferências Municipais e Estaduais - é de vital importância para o fortalecimento e a defesa do SUS. A contribuição de cada profissional, gestor, docente ou discente de enfermagem nesses processos garantirá que o bem cuidar seja, mais uma vez, reafirmado como direito inalienável de todos.

Helena Maria Scherlowski Leal David Diretora da Faculdade da UERJ Editora Associada 
